\title{
DAMPAK PEMBELAJARAN JARAK JAUH (PJJ) DI PERGURUAN TINGGI PADA MASA WABAH PANDEMI COVID-19 TERHADAP PEMAHAMAN MATERI MAHASISWA
}

(Studi Eksploratif Mahasiswa Sarjana PAI IAIN Salatiga)

\author{
Abdul Khamid \\ Institut Agama Islam Negeri Salatiga, Indonesia \\ Email: abdulkhamied33@gmail.com \\ Muchamad Chairul Umam \\ Institut Agama Islam Negeri Salatiga, Indonesia \\ Email: much.umam26@gmail.com
}

\begin{abstract}
This study aims to determine how the strategies carried out during distance learning (PJJ) during the Covid-19 pandemic outbreak of PAI IAIN Salatiga undergraduate students. Then the impact of the advantages or positives from the implementation of distance learning (PJJ), as well as the inhibiting factors. This research uses a qualitative approach. Primary data were collected using google form and secondary data from articles or journals, books and literature related to this research. From this research, it is known that the strategy for implementing distance learning (PJJ) in Salatiga is to take advantage of technological developments such as: zoom meetings, whatsapp groups, google forms, google classroom, google meet, and youtube. As for the positive or supporting impacts, namely: a) knowing the various applications and developments in science and technology, $b$ ) anticipating the rate of spread of the Covid-19 virus outbreak, c) PJJ is more lenient in time without requiring to come to the campus, it is enough to learn from their respective homes, d) material well and can spend more time with family. While the inhibiting effects are: a) lack of understanding in understanding the material, b) lack of maximal in lectures due to signal constraints, $c$ ) lack of interaction from student to lecturer or student to other students, $d$ ) most of them give assignments without the delivery of material first.
\end{abstract}

Keywords: Exploratory Studies, Distance Learning (PJJ), Covid-19

ABSTRAK

Penelitian ini bertujuan untuk mengetahui bagaimana strategi yang dijalankan selama perkuliahan pembelajaran jarak jauh (PJJ) dimasa wabah pandemi Covid-19 terhadap mahasiswa Sarjana PAI IAIN Salatiga. Kemudian dampak kelebihan atau positif dari pelaksanaan perkuliahan pembelajaran jarak jauh (PJJ), serta faktor penghambatnya. Penelitian ini menggunakan pendekatan kualitatif. Data primer dikumpulkan menggunakan google form dan data sekunder dari artikel atau jurnal-jurnal, buku dan literatur yang terkait dengan penelitian ini. Dari penelitian tersebut diketahui, strategi pelaksanaan pembelajaran jarak jauh (PJJ) Salatiga yaitu memanfaatkan perkembangan teknologi seperti: zoom meeting, whatsapp grup, google form, google classroom, google meet, dan youtube. Adapun dampak positif atau penunjang yaitu: a) mengetahui berbagai macam aplikasi dan perkembangan IPTEK, b) mengantisipasi laju penyebaran wabah virus Covid-19, c) PJJ lebih longgar waktunya dengan tidak mengharuskan datang kekampus cukup belajar dari rumah masing-masing, d)tersampaikan nya materi dengan baik dan waktunya lebih banyak bisa berkumpul dengan keluarga. Sedangkan dampak penghambat yaitu: a) kurangnya pemahaman dalam memahami materi, b) kurangnya maksimal dalam perkuliahan karena kendala sinyal, c) kurang nya interaksi dari mahasiswa ke dosen ataupun mahasiswa ke mahasiswa lainnya, d) kebanyakan memberikan tugas tanpa adanya penyampaian materi terlebih dulu.

Kata kunci: Studi Eksploratif, Pembelajaran Jarak Jauh (PJJ), Covid-19

\section{A. Latar Belakang}

Dunia kini sedang dilanda wabah corona virus disease (Covid-19). Virus yang sangat mematikan ini pertama kali muncul di kota Wuhan, China telah menyebar ke lebih 
dari 200 Negara yang mayoritas warganya beragama Islam. Berbagai kebijakan telah diambil oleh para kepala Negara untuk memotong mata rantai penyebaran Covid-19 ini. Selain menimbulkan masalah besar terhadap kesehatan, ekonomi, sosial, dan politik, yang tidak kalah menariknya lagi, implikasi Covid-19 juga telah memasuki ranah keagamaan. Diantara aspek keagamaan yang terdampak secara kasat mata di tengah badai Covid-19 adalah diperlakukannya pengaturan dalam praktik ritual keagamaan terutama yang dilakukan secara bersama-sama. ${ }^{1}$ Saat ini hampir seluruh belahan dunia sedang dalam fase menghadapi tantangan berupa pandemi yang berasal dari virus bernama Covid-19, tak terkecuali Indonesia. Sebagai salah satu Negara yang terdampak musibah penyakit mematikan ini, Indonesia mencoba bertahan dengan menerapkan kebijakan yang sesuai dengan anjuran Badan Kesehatan Dunia (WHO). Mulai dari protokol kesehatan, berupa menerapkan PSBB, physical distancing, kebijakan bekerja-beribadah-belajar dari rumah, yang mulai diberlakukan dihampir seluruh bagian daerah Indonesia. Adanya kebijakan-kebijakan tersebut kiranya dapat membantu tetap terjaganya sistem pemerintahan, perekonomian, termasuk pendidikan agar tidak mandeg dan tidak terkesan mati suri. Demikian halnya pemerintah Indonesia yang mulai menyuarakan tentang New Normal kepada masyarakat. Istilah New Normal atau kebiasaan baru merupakan sebuah perubahan gaya hidup yang menyesuaikan dalam situasi pandemi Covid-19. ${ }^{2}$

Di masa pandemi saat ini, segala upaya dikerahkan agar keberlangsungan kehidupan tetap berjalan. Tidak dapat dipungkiri bahwa pandemi Covid-19 memberikan dampak bagi pelaksanaan pembelajaran, baik dari setingkat pendidikan dasar hingga pendidikan tinggi. Sudah bukan hal baru bagi perguruan tinggi untuk melaksanakan perkuliahan yang sesuai dengan kondisi seperti ini. Sebagaimana anjuran yang disampaikan WHO, pemerintah Indonesia telah menginstruksikan untuk menerapkan belajar mengajar di rumah guna menghentikan penyebaran virus Covid-19. Menurut Zhafira dalam penelitiannya menyatakan pembelajaran daring dilakukan oleh hampir seluruh institusi pendidikan "demi memutus rantai penyebaran virus dan menjaga keselamatan serta kesehatan peserta didik dan tenaga pendidik". ${ }^{3}$ Secara tidak langsung, juga menerapkan self-quarantine and social distancing. ${ }^{4}$ Perkuliahan online sangat bergantung pada pemanfaatan jaringan internet dan perangkat teknologi, tak terkecuali dalam masa pandemi Covid-19. ${ }^{5}$

Dengan demikian untuk menghadapi perkuliahan online di perguruan tinggi tentunya tidak akan lepas dari hambatan,baik itu dari dosen maupun mahasiswa. Bahkan menurut penelitian Rodame Monitorir Napitupulu menyatakan bahwa Secara

\footnotetext{
${ }^{1}$ Wachyudi Achmad, "Peran dan Tantangan Pendidikan Agama Islam di Era Pandemi Covid-19 pada Lingkungan Keluarga” Journal Of Islamic Education, Vol. 5 No. 2 November 2020, 120.

2 Pragholapati, Andria. New Normal "Indonesia" After Covid-19 Pandemic, UPI, 2020 May 25, 2. DOI 10.31234/osf.io/7snqb, 2.

${ }^{3}$ Zhafira, Nabila Hilmy, Yenny Ertika, dan Chairiyaton. (2020). Persepsi Mahasiswa terhadap Perkuliahan Daring Sebagai Sarana Pembelajaran Selama Masa Karantina Covid-19. Jurnal Bisnis dan Kajian Strategi Manajemen Volume 4 Nomor 1, 2020, 37 - 45.

${ }^{4}$ Abidah, The Impact of Covid-19 to Indonesian Education and Its Relation to the Philosophy of "Merdeka Belajar", Studies in Philosophy of Science and Education (SiPoSE). Volume 1 Nomor 1 April 2020, 44.

5 Robert Connor Chick, Using Technology to Maintain the Education of Residents During Covid-19 Pandemic, Journal of Surgical Education, Volume 00 Nomor $00 \quad$ Maret 2020 , https://doi.org/10.1016/j.jsurg.2020.03.018, 1.
} 
keseluruhan, baik dari sisi teknologi maupun sisi dosen, mahasiswa tidak puas dengan metode PJJ yang dijalaninya saat ini dan juga merasa tidak puas dengan kemampuan dosen dalam menyampaikan materi pada PJJ. ${ }^{6}$ Akan tetapi walaupun banyak hambatan mau tidak mau pembelajaran harus tetap dilaksanakan sebagaimana anjuran dari pemerintah untuk tetap belajar dari rumah, ${ }^{7}$ sehingga dalam situasi seperti sekarang ini keseriusan mahasiswa dalam kuliah sedang diuji, apakah mahasiswa tersebut benar-benar sudah memahami materi yang disampaikan oleh dosen atau malah sama sekali belum paham yang disebabkan oleh keterbatasan dosen dalam mengontrol mahasiswa secara langsung. Berdasarkan masalah di atas maka perlunya penelitian tentang dampak pembelajaran jarak jauh di perguruan tinggi pada masa wabah Covid 19 terhadap pemahaman materi mahasiswa.

\section{B. Metode Penelitian}

Jenis penelitian dalam tulisan menggunakan pendekatan kualitatif (qualitative research), yaitu penelitian yang ditujukan untuk mendeskripsikan dan menganalisis fenomena, peristiwa, aktifitas sosial, sikap, kepercayaan, persepsi, pemikiran orang secara individu maupun kelompok, ${ }^{8}$ dimana data yang disajikan tidak dalam bentuk angka-angka melainkan dalam bentuk kata-kata dan gambaran-gambaran, ${ }^{9}$ sehingga hasil penelitiannya berupa deskripsi, interpretasi bagaimana dampak pembelajaran jarak jauh (PJJ) mahasiswa Sarjana PAI IAIN Salatiga dalam situasi Covid 19.

Ukuran sampel didasarkan pada pencapaian kedalaman dan kekayaan diskripsi. Dalam penelitian ini, responden sebanyak 10 mahasiswa ataupun mahasiswi Sarjana PAI IAIN Salatiga. Penelitian ini dilakukan semi terstruktur,

sementara daftar pertanyaan disusun dan disebarkan melalui alamat link google form dengan link: https://form.gle/onPymSHkLierrFag8 dengan dikembangkan berdasarkan buku atau literatur terkait. Pernyataan responden pada

penelitian ini adalah para mahasiswa dan mahasiswai sarjana PAI IAIN Salatiga.

Penelitian ini dilakukan hanya terbatas pada 10 mahasiswa ataupun mahasiswi sarjana PAI IAIN Salatiga yang dipilih secara acak. Penelitian ini menggunakan instrumen pertanyaan yang dikemas dalam bentuk form (google form) yang disebarkan melalui pesan whatsapp. Sedangkan data sekunder dikumpulkan dari data yang dipublikasikan seperti artikel, jurnal-jurnal dan buku terkait.

Dalam penelitian tulisan ini penulis menggunakan beberapa langkah yang berkaitan dengan metode penelitian tersebut yaitu: pertama, memberikan link google form kepada seluruh mahasiswa ataupun mahasiswi Sarjana PAI IAIN Salatiga. Tahap kedua peneliti melakukan pengamatan dan pencatatan dari sistematika fenomena-

${ }^{6}$ Rodame Monitorir Napitupulu, " Dampak pandemi Covid-19 terhadap kepuasan pembelajaran jarak jauh”, Jurnal Inovasi Teknologi Pendidikan Volume 7, No. 1, April 2020, 23-33.

${ }^{7}$ Zaharah, Galia Ildusovna Kirilova, Anissa Windarti, "Impact of Corona Virus Outbreak Towards Teaching and Learning Activities in Indonesia", Salam; Jurnal Sosial \& Budaya Syar-i FSH UIN Syarif Hidayatullah Jakarta Vol. 7 No. 3 (2020), 269-282.

${ }^{8}$ Nana Syaodih Sukmadinata, Metode Penelitian Pendidikan, Bandung. Remaja Rosdakarya, 2010, 60-61

${ }^{9}$ Burhan Bungin, Metodologi Penelitian: Format-Format Kuantitatif dan Kualitatif Surabaya: Airlangga University Press, 2005, 103. 
fenomena yang diselidiki. ${ }^{10}$ Peneliti melakukan pengamatan secara tidak langsung karena mengikuti anjuran pemerintah untuk social distancing. Ketiga, peneliti atau penulis melakukan dokumentasi guna mencari data yang relevan serta memperkuat data lapangan yang telah diperoleh berupa penelitian terdahulu, artikel, atau buku yang terkait. ${ }^{11}$ Selain itu, peneliti atau penulis juga mengumpulkan data yang berupa catatan tertulis.

Analisis data digunakan awal penelitian hingga akhir pengumpulan data yang bersifat terbuka dan induktif, sehingga tidak menutup kemungkinan akan terjadi reduksi data, perbaikan dan verifikasi atas data yang diperoleh hal ini dimaksudkan untuk lebih mempermudah pemahaman dan kejelasan. Teknik analisis data adalah proses kategori urutan data, mengorganisasikan kedalam suatu pola, kategori dan suatu uraian dasar, membedakannya dengan penafsiran yaitu memberikan arti yang signifikan terhadap analisis, menjelaskan pola uraian dan mencari hubungan diantara dimensi-dimensi uraian. $^{12}$ Aktivitas dalam analisis data dalam penelitian ini terdiri dari: pertama, penyajian data yaitu dengan mendeskripsikan hasil data yang diperoleh melalui angket forms (google forms) dengan menggunakan kalimat dengan pendekatan kualitatif, sehingga diperoleh laporan yang sistematis dan mudah untuk dipahami. Kedua, mereduksi data angket yang terkumpul dengan merujuk pada fokus utama, ${ }^{13}$ untuk kemudian dicari tema dan polanya. Berikutnya tahap ketiga, yaitu penarikan kesimpulan dari hasil pengumpulan data kemudian direduksi dan diverifikasi. Setelah melakukan verifikasi, tahap selanjutnya adalah mencari kesimpulan akhir. Peneliti atau penulis menilai bahwa validitas data merupakan faktor penting dalam sebuah penelitian karena sebelum data dianalisis terlebih dahulu harus mengalami pemeriksaan. Selain itu, validitas membuktikan bahwa hasil yang diamati sudah sesuai dengan kenyataan atau benar-benar terjadi. Teknik pengujian validitas data yang digunakan dalam penelitian ini menggunakan triangulasi untuk menguji keabsahan dengan memanfaatkan suatu yang lain dari data itu sendiri. ${ }^{14}$

Dalam penelitian ini teknik triangulasi yang digunakan yaitu: triangulasi data yaitu mengumpulkan data yang sejenis dari beberapa sumber data yang berbeda dan triangulasi metode dilakukan dengan menggali data yang sama dengan metode yang berbeda.

Tabel 1.1 Data Responden Mahasiswa Sarjana IAIN Salatiga

\begin{tabular}{|l|l|l|}
\hline \multicolumn{1}{|c|}{ No } & \multicolumn{1}{|c|}{ Nama Mahasiswa } & \\
\hline 1. & Umi Nurmalina & Banjarnegara, Jawa Tengah \\
\hline 2. & Hana Qurrota A'yun & Kendal \\
\hline 3. & Fety Unjiyati & Ds.Tempuranduwur, Kec.Sapuran, Kab. \\
\hline
\end{tabular}

\footnotetext{
${ }^{10}$ Sutrisno Hadi, Metodologi Researt, Yogyakarta: Andi Offet, 2003, 136.

${ }^{11}$ Suharsimi, Arikunto, Prosedur suatu Penelitian suatu Pendekatan Praktis, Jakarta: Renika Cipta, 2002,

${ }^{12}$ Lexy J Moelong, Metodologi Penelitian Kualitatif, Bandung: Remaja Rosdakarya, 2009, 280.

${ }^{13}$ Sugiyono, Metode Penelitian Pendidikan: Pendekatan Kuantitatif, kualitatif dan $R \& D$. Bandung,

.${ }^{14}$ Lexy J Moelong, Metodologi Penelitian Kualitatif, Bandung: Remaja Rosdakarya, 2009, 330.
} 148. Alfabeta, 2010, 247. 


\begin{tabular}{|l|l|l|}
\hline 4. & Sri puji jayanti & Sumur, brangsong, kendal \\
\hline 5. & Busro Mustofa & Wates Kedungjati \\
\hline 6. & M. Alfan Miftahul Fauzi & Lampung \\
\hline 7. & Anik karmania sekar ayu & Ds.Medani kec. Tegowanu kab. Grobog: \\
\hline 8. & M. Miftahu ni'am & Seniman, pati \\
\hline 9. & Itsna Ma'rifa & Kebumen \\
\hline 10. & Rizqi Fadhilatul Munawaroh & Kradenan, Grobogan \\
\hline
\end{tabular}

\section{Hasil Penelitian}

IAIN Salatiga yang berada di Kota Salatiga merupakan salah satu lembaga perguruan tinggi pendidikan yang bagian ikut serta merasakan imbas adanya pandemi wabah Covid-19 yang berkembang saat ini. Berbagai himbauan dari pemerintah untuk memberikan pelarangan sementara berkaitan tempat belajar mengajar yang biasa berlangsung setiap harinya, yang pada hakikatnya belajar mengajar yang semula terpusat di kampus IAIN Salatiga saat ini dialihkan belajar dari rumah masing-masing mahasiswa IAIN Salatiga. Adapun tujuan dari penelitian ini yaitu untuk mendapatkan berbagai informasi seputar: Dampak Pembelajaran Jarak Jauh (PJJ) di Perguruan Tinggi pada Masa Wabah Pandemi Covid-19 Terhadap Pemahaman Materi Mahasiswa (Studi Eksploratif Mahasiswa Sarjana PAI IAIN Salatiga)

Dari semua tanggapan responden atau narasumber asli dan mereka telah dikutip sebagaimana dinyatakan oleh para responden. Setelah melaksanakan penelitian menggunakan angket form (google form), diperoleh beberapa pernyataan yang disampaikan oleh para narasumber atau responden diantaranya sebagai berikut: Responden (UN) memberikan tanggapan tentang bagaimana strategi pelaksanaan perkuliahan mahasiswa Sarjana PAI IAIN Salatiga selama situasi wabah pandemi Covid19: “semua mahasiswa Sarjana PAI IAIN Salatiga mengikuti semua bentuk rangkaian perkuliahan melalui peningkatan teknologi dan dilaksanakan di rumah masing-masing”,

Responden lain (HKA) dan (FN) memberikan komentar diantaranya: “dalam pelaksanaan perkuliah jarak jauh saat pandemi Covid-19 seperti saat ini melalui pemanfaatan beberapa kemajuan teknologi yang berkembang saat ini seperti: WAG, Google Meet, Google Classroom, Zoom Metting, dan Youtube”

Peryataan di atas hampir sejalan dengan peryataan (SPJ) yaitu: "pembelajaran dengan penuh memanfaatkan perkembangan teknologi WAG, Google Classroom dll, yang berkembang saat ini sehingga pembelajaran tetap bisa berjalan dengan baik"

Beberapa pernyataan diatas memberikan sebuah gambaran awal bahwasanya dimasa yang serba sulit seperti saat ini atau masa pandemic Covid-19 pembelajaran tetap berjalan walaupun dengan pembelajaran jarak jauh (PJJ) dengan berbagai strategi dilakukan untuk tetap bisa berjalannya penyampaian materi kuliah Sarjana PAI IAIN Salatiga dengan berbagai pemanfaatan perkembangan teknologi yang serba canggih seperti saat ini yang banyak digunakan oleh para mahasiswa Sarjana PAI IAIN Salatiga. 
Adapun responden lainnya memberikan beberapa komentar atau tanggapan berkenaan dampak kelebihan dan dampak kelemahan dalam pelaksanaan perkuliahan jarak jauh (PJJ) dalam situasi wabah pandemi Covid-19 terhadap pemahaman materi perkuliahan mahasiswa Sarjana PAI IAIN Salatiga.

(BM) memberikan peryataan atau tanggapan: "dalam pelaksanaan perkuliah jarak jauh (PJJ)) mahasiswa dapat mengetahui berbagai macam aplikasi pembelajaran yang sebelumnya jarang bahkan belum pernah dilaksanakan"

Peryataan hampir serupa muncul dari (MAM) yaitu: “ perkuliahan jarak jauh $(P J J))$ Lebih memahami iptek dan pastinya dapat memanfaatkan perkembangan teknologi"

(MMN) memberikan tanggapan: "kita bisa mengantisipasi untuk penyebaran virus Covid-19 dan waktunya bisa lebih banyak dimanfaatkan dengan keluarga”

Diikuti tanggapan lainnya (RFM) "selain perkuliahan dekat denga keluarga juga bisa mengerjakan tugas lainnya dan waktunya perkuliahan agak longgar dengan tidak harus datang kekampus"

Responden lainnya (IM): "Pembelajaran jarak jauh (PJJ) tetap bisa terlaksana walaupun tidak diikuti tatap muka sehingga terhindar penyakit Covid-19 dengan harapan dapat memutus rantai laju penyebaran virus Covid-19”.

Peryataan atau tanggapan narasumber atau responden diatas memberikan sebuah gambaran awal bahwasannya dalam masa wabah pandemi Covid-19 seperti saat ini, masih tetap bisa melaksanakan kegiatan penyampaian materi menggunakan pembelajaran jarak jauh (PJJ) Sarjana PAI IAIN Salatiga walaupun pada prateknya masih dijumpai berbagai tantangan,tetapi sedidaknya tidak melemahkan mahasiswa untuk tetap belajar dimasa sulit dengan baik dan memahami materi-materi yang diberikan oleh para dosen, pembelajaran jarak jauh (PJJ) adalah bagian dari solusi yang baik dengan harapan memutus rantai penyebaran wabah pandemi Covid-19.

Selain dampak kelebihan atau positif dijumpai pula dampak kelemahan dengan adanya pelaksanaan penyampaian materi kuliah melalui pembelajaran jarak jauh (PJJ), beberapa responden memberikan tanggapan sebagi berikut:

(RFM) memberikan tanggapan: "Kurangnya pemahaman dalam memahami materi yang kita pelajari,tapi itu juga tergantung pada pribadi masing-masing jika dia giat dan mau belajar mengulang memahami materi insya Allah akan paham”,

Diikuti responden lainnya (BM) memberikan tanggapan: "Kurang maksimal dalam perkuliahan karena kendala sinyal, kurang tersampainya materi yang diajarkan"

(SPJ) memberikan tanggapan: "dalam pelaksanaan pembelajaran jarak jauh (PJJ) Kurang nya interaksi baik dari mahasiswa ke dosen ataupun mahasiswa ke mahasiswa lainnya”.

Responden lain memberikan tanggapan (AKS) yaitu: “dalam pelaksanaan pembelajaran jarak jauh (PJJ) masih didapati sebagian dosen kebanyakan memberikan tugas tanpa adanya penyampaian materi terlebih dulu”.

Peneliti melihat keseluruhan semua mahasiswa Sarjana PAI IAIN Salatiga merasakan dampak penunjang atau positif dengan diadakannya pembelajaran jarak jauh (PJJ) yang 
diberikan oleh lembaga kampus. Namun, sebagaimana pendapat diatas bahwa selain dampak penunjang atau positif masih didapati juga adanya hambatan dalam proses pelaksanaan pembelajaran jarak jauh pada masa wabah pandemi Covid-19 saat ini.

\section{Pembahasan}

1. Strategi Pembelajaran Jarak Jauh (PJJ) Mahasiswa Sarjana PAI IAIN Salatiga di masa Wabah Pandemi Covid-19

Strategi sendiri berasal dari bahasa yunani yaitu strategos yang artinya suatu usaha untuk mencapai suatu kemenangan dalam suatu peperangan awalnya digunakan dalam lingkungan militer namun istilah strategi digunakan dalam berbagai bidang yang memiliki esensi yang relatif sama termasuk diadopsi dalam konteks pembelajaran yang dikenal dalam istilah strategi pembelajaran. ${ }^{15}$

Strategi pembelajaran merupakan suatu rencana tindakan (rangkaian kegiatan) yang termasuk juga penggunaan metode dan pemanfaatan berbagai sumber daya/kekuatan dalam pembelajaran.

Maka pembelajaran yang diterapkan Guru/Dosen akan tergantung pada pendekatan yang digunakan: sedangkan bagaimana menjalankan strategi itu dapat diterapkan berbagai metode pembelajaran. Dalam upaya menjalankan upaya metode pembelajaran seorang Guru/Dosen dapat menentukan teknik yang dianggapnya relevan dengan metode, dan penggunaan teknik setiap Guru/Dosen mempunyai berbeda dari satu ke lainnya. Mohammad Salehudin dalam penelitiannya menyatakan bahwa kemampuan guru/dosen sebagai pengguna media social yang diadopsi menjadi e-learning pada PJJ disaat Indonesia pandemic civid-19 adalah diatas nilai baik dan bahkan sangat baik dikarenakan keadan saat ini memang menuntut untuk demikian. ${ }^{16}$

Dunia saat ini dalam situasi yang sangat darurat terkhusus Negara Indonesia baru mengalami wabah pandemi Covid-19 atau biasa masyarakat sebut dengan sebutan corona. Hal ini membuat hampir seluruh sektor mengalami perubahan tidak terlepas juga dalam dunia pendidikan mulai dari tingkatan bawah sampai kepada tingkat perkuliahan, semuanya mengalami proses pembelajaran yang berbeda dengan pembelajaran sebelumnya, hal ini bisa kita jumpai saat ini dimana awalnya pembelajaran dilaksanakan denga tatap muka baik guru/dosen dan murid/ mahasiswa dalam satu ruangan, kini semua kegiatan diliburkan dan digantikan dengan pembelajaran jarak jauh (PJJ) di rumah masing-masing.

Hal serupa dirasakan juga oleh mahasiswa Sarjana PAI IAIN Salatiga, dalam menghadapi pembelajaran seperti saat ini pastinya membutuhkan kesiapan dan kesepakatan bersama anatara dosen dan mahasiswa guna menciptakan strategi baru dalam menerapkan proses pembelajaran jarak jauh (PJJ) yang sebelumnya belum pernah dilaksanakan, hal ini perlunya pemerhatian bersama dengan harapan tetap tersampaikan nya materi perkuliahan dan tetap mentaati anjuran pemerintah guna memutus rantai penyebaran virus Covid-19. Dengan diberlakukannya pembelajaran jarak jauh (PPJ) membutuhkan bantuan teknologi

${ }^{15}$ Abdul Majid, Strategi Pembelajaran, Bandung: PT. Remaja Rosdakarya, 2014, 3.

16 Mohammad Salehudin, "Dampak Covid-19: Guru Mengadopsi Media Sosial Sebagai E-Learning Pada Pembelajaran Jarak Jauh", Jurnal MUDARRISUNA Vol. 10 No. 1 Januari-Maret 2020, 1-14. 
yang mumpuni dan dapat diakses dengan mudah oleh banyak mahasiswa dengan harapan tetap tersampaikannya materi pembelajaran, dengan demikian maka perlunya IAIN Salatiga berkoordinasi dan mensosialisasikan untuk melaksanakan pembelajaran jarak jauh (PJJ) dengan berbagai strategi diserahkan kepada dosen pengampu masing-masing sehingga pembelajaran perkuliahan tetap berjalan sebagaimana mestinya sesuai dengan jadwal perkuliahan masing-masing mahasiswa Sarjana PAI IAIN Salatiga.

Meskipun demikian pelaksanaan pembelajaran jarak jauh (PJJ) atau perkuliahan daring juga membutuhkan strategi agar dalam proses pembelajaran dosen menyampaikan materi kepada mahasiswa dapat berlangsung secara efektif. Hal ini perlunya koordinasi yang baik terbuka antara dosen dengan mahasiswa. Beberapa dosen memberlakukan WAG khusus sesuai dengan kelas masing-masing sesuai mata kuliah yang diampu oleh dosen dengan adanya grup tersebut akan memudahkan dalam berkomunikasi antara dosen dengan mahasiswa. Dari pengamatan peneliti, penjelasan di atas merupakan bentuk strategi sebelum pelaksanaan perkuliahan daring diadakan. Tahapan berikutnya, dosen dapat memanfaatkan situasi tersebut untuk memulai perkuliahan daring dengan pemanfaatan teknologi.

Tabel 1.2 Daftar aplikasi Pembelajaran Jarak Jauh (PJJ) di masa wabah pandemi Covid-19 mahasiswa Sarjana PAI IAIN Salatiga

\begin{tabular}{|l|l|}
\hline \multicolumn{2}{|c|}{ Aplikasi Pembelajaran Jarak Jauh (PJJ) masa Pandemi Covid-19 } \\
\hline 1. Zoom Meeting & Google Classroom \\
\hline 2. Whatsapp grup & Google Meet \\
\hline 3. Google Form & Youtube \\
\hline
\end{tabular}

Maka dengan demikian dari hasil wawancara diketahui bahwa mahasiswa Sarjana PAI IAIN Salatiga tetap melaksanakan perkuliahan pembelajaran jarak jauh (PJJ) dengan memanfaatkan berbagai media teknologi seperti zoom meeting, whatsapp grup, google form, google classroom, google meet, dan youtube. Keenam aplikasi tersebut terbutki cukup dirasa efektif dalam menunjang pelaksanaan pembelajaran jarak jauh (PJJ).

Adapun kaitan dengan pemahaman materi yang telah diajarkan para dosen, semua mahasiswa Sarjana PAI IAIN Salatiga mendapatkan kemudahan informasi melalui grup whatsapp yang sebelumnya sudahdi desain guna memudahkan informasi, mahasiswa dapat menanyakan berkaitan tugas/materi kuliah yang belum dimengerti. Selain melalui whatsapp mahasiswa Sarjana PAI IAIN Salatiga juga dapat mencari sumber informasi tersebut melalui aplikasi yang dimiliki oleh perpustakaan kampus IAIN Salatiga yakni perpustakaan digital atau mesin pencari google. Sehingga, para mahasiswa dapat memahami materi melalui perkuliahan pembelajaran jarak jauh (PJJ) dapat terpenuhi dengan baik dan tetap efektif dengan tetap mematuhi arahan dari pemerintahan.

Maka dengan demikian para Mahasiswa Sarjana PAI IAIN Salatiga selama wabah pandemi Covid-19 ini tetap mendapatkan pembelajaran sesuai dengan materi-materi yang sudah disampaikan dosen di awal kontrak belajar. Selain bisa lebih leluasa dalam mengerjakan pekerjaan rumah dan lebih dekat dengan orang tua tentunya aktivitas belajar tetap berjalan dengan baik, dengan demikian pemahaman-pemahaman para mahasiswa tetap berjalan sebagaimana mestinya tetap mendapatkan haknya dalam mengikuti pembelajaran 
hanya saja yang membedakan dengan sebelumnya adalah saat ini tempat belajarnya saja yang berbeda selama masa wabah pandemi Covid-19 ini berlangsung. Startegi ini dirasa cukup menarik dan bagus disaat wabah menyerang saat ini dan para mahasiswa Sarjana PAI IAIN Salatiga untuk tetap belajar dan selalu mendakwahkan ilmu agama Allah terkhusus Mahasiswa Sarjana yang mengambil jurusan Pendidikan Agama Islam di IAIN Salatiga di tengah wabah pandemi Covid-19 dengan tetap belajar dengan sebaik-baiknya. Dan yang tidak kalah pentingnya adalah senantiasa membiasakan gaya hidup bersih serta selalu mematuhi protokol kesehatan sebagai bentuk mengikuti aturan atau anjuran dari pemerintah demi kebaikan bersama.

\section{Dampak Penunjang Pembelajaran Jarak Jauh (PJJ) terhadap Pemahaman Materi Sarjana PAI IAIN Salatiga}

Sebagaimana kita ketahui bahwa virus Covid-19 tidak hanya terjadi di Indonesia saja melainkan juga menjangkiti hampir seluruh belahan dunia, virus tersebut tentunya memberikan dampak yang cukup nyata baik dampak pada sektor ekonomi ataupun dampak pada sektor pendidikan juga merasakan ganasnya terjangan virus Covid-19. Hal tersebut menyebabkan sektor pendidikan mau tidak mau harus mengambil langkah untuk tetap melaksanakan pembelajaran walaupun berbeda dengan pembelajaran sebelumnya. Di dalam dunia pembelajaran yang serba baru saat ini dan belum pernah dirasakan sebelumnya pastinya memunculkan dampak penunjang atau positif dan adapula kelemahannya dalam penerapan pembelajaran jarak jauh (PJJ) yang berkembang saat ini.

Potret dunia pendidikan saat ini dalam situasi yang kurang stabil khususnya dalam melaksanakan proses pembelajaran, akan tetapi para mahasiswa Sarjana PAI IAIN Salatiga dengan tekat semangat tetap melangsungkan pembelajaran menggunakan pembelajaran jarak jauh (PJJ). Melihat kondisi yang serba sulit dalam belajar namun dibalik itu semuanya masih merasakan dampak penunjang ataupun dampak positif dari diadakannya perkuliahan jarak jauh, karena dibalik setiap peristiwa yang terjadi pasti tersimpan sebuah hikmah yang mendalam khususnya dalam menghadapi Covid 19 ini, sehingga bagaiamanapun keadaannya proses belajar mengajar harus tetap dilaksanakan demi terciptanya kemaslahatan bersama.

Dari hasil penelitian, penulis mencoba untuk menuangkan dan menguraikan dampak penunjang atau dampak positif dari adanya cobaan wabah pandemi Covid-19 pada pembelajaran mahasiswa Sarjana PAI IAIN Salatiga. Di antara dampak penunjang yang dirasakan oleh mahasiswa PAI IAIN Salatiga adalah pertama: dengan adanya pembelajaran jarak jauh (PJJ) mahasiswa Sarjana PAI IAIN Salatiga dapat mengetahui berbagai macam aplikasi pembelajaran yang sebelumnya jarang bahkan belum pernah dilaksanakan. Hal ini adalah salah satu bagian dari dampak penunjang yakni mengikuti perkembangan teknologi yang berkembang saat ini. Kedua, PJJ memberikan kebaikan kepada kita semuanya untuk ikut serta menghambat laju penyebaran wabah virus Covid-19 dan dengan adanya PJJ ini

mahasiswa Sarjana PAI IAIN Salatiga waktunya bisa lebih banyak dimanfaatkan untuk berkumpul dengan keluarga. Ketiga, selain tetap bisa melaksanakan proses beajar mengajar, mahasiswa memiliki lebih banyak waktu luang untuk melakukan sesuatu yang bermanfaat seperti membantu pekerjaan orang tua di rumah karena mahasiswa tidak perlu 
datang ke kampus. Keempat, tetap terlaksanakanya penyampaian materi oleh dosen walaupun tidak secara tatap muka langsung, dengan demikian akan memutus penyebaran virus corona dan berharap virus corona segera berakhir sehingga bisa melaksanakan kembali pembelajaran tatap muka seperti dahulu kala.

\section{Dampak Penghambat Pembelajaran Jarak Jauh (PJJ) terhadap Pemahaman Materi Sarjana PAI IAIN Salatiga}

Seperti informasi yang berkembang saat ini melalui berbagai informasi baik media cetak ataupun melalui siaran Televisi dunia menghadapi virus mematikan dengan sering disebutnya virus Covid-19, Indonesia sendiri adalah bagian dari salah satu Negara yang turut terkena imbas adanya virus wabah pandemi Covid-19 yang terjadi hampir di seluruh dunia, wabah pandemi Covid-19 menyebabkan pemerintahan Indonesia turut mengambil atau mengeluarkan beberapa kebijakan dibebagai sektor tidak terlepas juga sektor pendidikan.

Kebijakan tersebut bagian dari ikhtiar pemerintah untuk memutus penyebaran virus Covid-19, pembelajaran yang mulanya tatap muka kini di alihkan dengan pembelajaran jarak jauh (PJJ). Diambil dari sudut pandang mahasiswa Sarjana PAI IAIN Salatiga pembelajaran jarak jauh (PJJ) merupakan salah satu metode baru yang belum pernah digunakan diperguruan tinggi IAIN Salatiga.

Berdasarkan penelitian survai penulis masih didapati beberapa hambatan dalam pelaksanaan pembelajaran jarak jauh (PJJ) bagaimanapun juga setiap pembelajaan pasti terdapat faktor penunjang dan faktor penghambatnya apalagi dalam dunia pendidikan yang belum pernah dilakukan selama ini, sehingga perlunya mahasiswa beradaptasi lebih berkenaan penggunaan media pembelajaran berbasis teknologi, dari sini penulis mencoba untuk memaparkan dari hasil penelitian dampak penghambat dalam pelaksanaan pembelajaran jarak jauh (PJJ) terhadap Mahasiswa Sarjana PAI IAIN Salatiga: Pertama,Kurangnya pemahaman dalam memahami materi yang kita pelajari,tapi itu juga tergantung pada pribadi masing-masing jika dia giat dan mau belajar mengulang memahami materi insya Allah akan paham. Kedua: dalam pembelajaran jarak jauh (PJJ) masih didapati kurangnya maksimal dalam perkuliahan karena kendala sinyal, kurang tersampainya materi yang diajarkan secara keseluruhan. Ketiga, dalam pelaksanaan pembelajaran jarak jauh (PJJ) Kurangnya interaksi baik dari mahasiswa ke dosen ataupun mahasiswa ke mahasiswa lainnya. Keempat, dalam pelaksanaan pembelajaran jarak jauh (PJJ) masih didapati sebagian dari dosen kebanyakan memberikan tugas tanpa adanya penyampaian materi terlebih dulu.

Dengan demikian walaupun dalam melaksanakan pembelajaran jarak jauh (PJJ) di masa pandemi Covid-19 terdapat faktor penunjang namun tidak menutup kemungkinan masih didapati faktor penghambat sebagaimana yang telah dipaparkan diatas. Dari hasil penelitian ini diarapkan dapat menjadikan perhatian dan informasi bagi para praktisi pendidikan khususnya di perguruan tinggi terkait dengan pembelajaran jarak jauh (PJJ).

\section{E. Kesimpulan}

Pelaksanaaan pembelajaran jarak jauh (PJJ) yang dialami oleh mahasiswa PAI IAIN Salatiga di masa Covid 19 saat ini tentu membutuhkan media pendukung untuk memudahkan proses pembelajaran, diantara media yang digunakan oleh mahasiswa PAI IAIN Salatiga 
selama pembelajaran yakni melalui zoom meeting, whatsapp grup, google form, google classroom, google meet, dan youtube. Meskipun demikian dalam pembelajaran jarak jauh (PJJ) terdapat dampak penunjang dan penghambat. Beberapa dampak penunjang pembelajaran jarak jauh pada mahasiswa PAI IAIN Salatiga yakni : a) mahasiswa menjadi paham dan mengetahui berbagai macam aplikasi dan perkembangan IPTEK, b) mengantisipasi laju penyebaran wabah virus Covid-19, c) PJJ lebih longgar waktunya dengan tidak mengharuskan datang ke kampus cukup belajar dari rumah masing-masing, d) tersampaikannya materi dengan baik dan waktunya lebih banyak bisa berkumpul dengan keluarga. Sedangkan dampak penghambatnya yakni: a) kurangnya pemahaman dalam memahami materi, b) kurangnya maksimal dalam perkuliahan karena terkendala sinyal, c) kurang nya interaksi dari mahasiswa ke dosen ataupun mahasiswa ke mahasiswa lainnya, d) kebanyakan memberikan tugas tanpa adanya penyampaian materi terlebih dulu.

\section{DAFTAR PUSTAKA}

Abdul Majid, Strategi Pembelajaran, Bandung: PT. Remaja Rosdakarya, 2014.

Abidah, "The Impact of Covid-19 to Indonesian Education and Its Relation to the Philosophy of "Merdeka Belajar", Studies in Philosophy of Science and Education (SiPoSE)," Volume 1 Nomor 1 April 2020.

Achmad, Wachyudi, "Peran dan Tantangan Pendidikan Agama Islam di Era Pandemi Covid-19 pada Lingkungan Keluarga" Journal Of Islamic Education, Vol. 5 No. 2 November 2020.

Arikunto, Suharsimi, Prosedur suatu Penelitian suatu Pendekatan Praktis, Jakarta: Renika Cipta, 2002.

Bungin, Burhan, Metodologi Penelitian: Format-Format Kuantitatif dan Kualitatif Surabaya: Airlangga University Press, 2005.

Chick, Robert Connor, "Using Technology to Maintain the Education of Residents During Covid-19 Pandemic, Journal of Surgical Education," Volume 00 Nomor 00 Maret 2020, https://doi.org/10.1016/j.jsurg.2020.03.018.

Hadi, Sutrisno, Metodologi Research, Yogyakarta: Andi Offet, 2003.

Moelong, Lexy J, Metodologi Penelitian Kualitatif, Bandung: Remaja Rosdakarya, 2009.

Napitupulu, Rodame Monitorir, "Dampak pandemi Covid-19 terhadap Kepuasan Pembelajaran Jarak Jauh”, Jurnal Inovasi Teknologi Pendidikan Volume 7, No. 1, April 2020.

Pragholapati, Andria. New Normal "Indonesia" After Covid-19 Pandemic, UPI, 2020 May 25, 2. DOI 10.31234/osf.io/7snqb.

Salehudin, Mohammad, "Dampak Covid-19: Guru Mengadopsi Media Sosial Sebagai ELearning Pada Pembelajaran Jarak Jauh”, Jurnal MUDARRISUNA Vol. 10 No. 1 Januari-Maret 2020.

Sugiyono, Metode Penelitian Pendidikan: Pendekatan Kuantitatif, kualitatif dan $R$ \& D. Bandung, Alfabeta, 2010.

Sukmadinata Nana Syaodih, Metode Penelitian Pendidikan, Bandung. Remaja Rosdakarya, 2010. 
Zaharah, Galia Ildusovna Kirilova, Anissa Windarti, "Impact of Corona Virus Outbreak Towards Teaching and Learning Activities in Indonesia”, Salam; Jurnal Sosial \& Budaya Syar-i FSH UIN Syarif Hidayatullah Jakarta Vol. 7 No. 3 (2020).

Zhafira, Nabila Hilmy, Yenny Ertika, dan Chairiyaton. (2020). "Persepsi Mahasiswa terhadap Perkuliahan Daring Sebagai Sarana Pembelajaran Selama Masa Karantina Covid-19.” Jurnal Bisnis dan Kajian Strategi Manajemen Volume 4 Nomor 1, 2020. 